J. Amer. Soc. Hort. Sci. 116(3):482-490. 1991.

\title{
Surface Color Changes of Tomato and Other Solanaceous Fruit during Chilling
}

\author{
Georges T. Dodds', J. Wyatt Brown', and Pamela M. Ludford ${ }^{3}$ \\ Vegetable Crops Department, Cornell University Ithaca, NY 14853-0327 \\ Additional index words. postharvest physiology, Lycopersicon esculentum, L. peruvianum, Solarium carolinense, S.
pennellii, S. pimpinellifolium, canonical variates analysis
}

Abstract. Chilling of mature-green (MG) tomato fruit (Lycopersicon esculentum Mill. and related species) was investigated to determine the effect of chilling stress on surface color during low-temperature storage. Color measurements were made with a tristimulus calorimeter ( $\mathrm{L}, \mathrm{a}, \mathrm{b}$ values), and data were analyzed by multivariate analysis of variance and canonical variates analysis. Changes in surface color of MG fruit during chilling were not correlated overall with relative chilling sensitivity of cultivars/lines; however, within standard and cherry types, chilling-tolerant fruit changed surface color more during chilling than chilling-sensitive fruit when fruit were picked early in the season. Early harvests were less chilling-sensitive than late harvests. The number of hours below $15.6 \mathrm{C}$ in the 200 hours before harvest was positively correlated with postharvest chilling sensitivity. A high vs. ambient relative humidity during storage did not affect chilling-induced percent change in color. Tobacco mosaic virus resistance led to less and Verticillium albo-strum Reinke \& Berthier resistance led to more chilling-induced color change. There was no effect from resistances to Fusarium oxysporum Schlechtend f. sp. lycopersici (Sacc.) W.C. Snyder \& H.N. Hans, alternaria stem canker (Alternaria solani Sorauer), anthracnose [Colletotrichun coccodes (Wallr.) S.J. Hughes], rootknot nematode (Meloidogyne hapla Chitwood), Phytophthora infestans (Mont.) deBary, or Stemphylium botryosum f. sp. lycopersici Rotem, Cohen, \& Wahl. Our results show harvest date had an effect on chilling-induced changes in surface-color in MG fruit.

When MG tomato fruit are subjected for extended periods to temperatures of $12.5 \mathrm{C}$ or lower but above the average freezing point of tomatoes $(-0.85 \mathrm{C})$ (Harvey and Wright, 1922), chilling injury (CI) develops during subsequent ripening at nonchilling temperatures (Morris, 1982). Delayed, partial, or uneven ripening, pitting, and an increased susceptibility to Alternaria alternata (Fr. : Fr.) Keissl. (syn. A. tenuis Nees) and other fruit rots are all symptomatic of CI (McColloch and Worthington, 1952). The severity of $\mathrm{Cl}$ increases with exposure (Autio and Bramlage, 1986; McColloch and Worthington, 1952, 1954; Tomkins, 1963), with lower storage temperature (Abdel-Maksoud et al., 1974; Efiuvwevwere and Thorne, 1988), and for fruit that are least ripe when chilled (Abou-Aziz et al., 1974b; Furlong, 1946). Hobson (1981) found early breaker fruit to be the most sensitive to CI. Tolerance to CI differs between tomato cultivars/lines (Abou-Aziz et al., 1974a; Gonzalez-Ramirez et al., 1978; King and Ludford, 1983; Segall et al., 1963).

Color development in MG tomato fruit during storage at chilling temperatures has generally been assessed subjectively. The normal red coloration from lycopene accumulation in ripe fruit did not develop when MG fruit were stored below 10C; however, some yellowing developed at temperatures down to $4 \mathrm{C}$ (Duggar, 1913; Furlong, 1946; Rosa, 1926). In an objective assessment, both chlorophyll and $\beta$-carotene decreased in MG 'Hikari' tomato fruit chilled at $4 \mathrm{C}$, whíle no lycopene accumulation was detected (Ogura et al., 1975).

During chilling at 5C, we observed that MG fruit of chillingtolerant cultivars appeared to turn yellow more quickly than

Received for publication 24 July 1990. We thank M. Mutschler, Dept. of Plant Breeding, Cornell Univ.; R. Robinson, New York State Agricultural Experiment Station, Geneva; and S. Valerie, U.S. Dept. of Agriculture Germplasm Resources, Geneva, N. Y., for samples of tomato fruit and seeds and K.S. Yourstone for statistical advice. The cost of publishing this paper was defrayed in part by the payment of page charges. Under postal regulations, this paper therefore must be hereby marked advertisement solely to indicate this fact.

'Graduate Student, botany.

${ }^{2}$ Graduate Student, vegetable crops.

${ }^{3}$ Associate Professor of Vegetable Crops. those of chilling-sensitive cultivars. The purpose of the present work was to investigate changes in fruit surface color measured objectively (Hunter, 1948) in chilled MG fruit with respect to chilling tolerance, fruit type, region of the fruit, genetic traits and related genera, disease resistances, chilling temperature, relative humidity, and preharvest field conditions. The results were analyzed by multivariate analysis of variance followed by canonical variates analysis.

\section{Materials and Methods}

The lines and cultivars and related species of Lycopersicon esculentum used in these experiments and their relevant characteristics are listed in Tables 1 and 2. Field-grown MG tomato fruit were hand-harvested in early September at the Homer C. Thompson Vegetable Research Farm, Freeville, N.Y. (1988); the East Ithaca Vegetable Research Farm, Ithaca, N.Y. (1988, 1989); and at the Vegetable Research Farm and U.S. Dept. of Agriculture Germplasm Resources plots, New York State Agricultural Experiment Station, Geneva (1989). Maturity of MG fruit was determined in the field using subjective evaluations of fruit size, position on plant, smoothness of fruit shoulder, and by observation of Iocular development in some representative fruit (Kader and Morris, 1976). The time of harvest (1330-1430 HR) was chosen as the one most likely to show the most CI (Saltveit and Cabrera, 1987). MG fruit of Solarium carolinense L. (horse-nettle) were obtained in mid-October from a corn field near Etna, N.Y. Temperature readings for the $200 \mathrm{~h}$ before harvest were obtained from the local Ithaca weather station (1989) and from a sheltered, field-located hygrothermograph (Model 5022 Hi-Q; WEATHERtronics, Sacramento, Calif.) at Freeville (1988). Temperatures were measured at a height of 1.5 and 1 $\mathrm{m}$ from the ground, respectively.

Fruit were dipped for $3 \mathrm{~min}$ in a 300-ppm Cl- solution (108 $\mathrm{ml}$ commercial bleach : 18.9 liters water at $\approx 30 \mathrm{C}$ ), dried, and placed stem scar down on sterilized plastic trays and chilled in

$\overline{\text { Abbreviations: }} \mathrm{CI}$, chilling injury MG, mature-green; TI, chilling tolerance index.

J. Amer. Soc. Hort. Sci. 116(3):482-490. 1991. 
Table 1. Comparison of chilling-tolerant and chilling-sensitive cultivars/lines (1988 and 1989).

\begin{tabular}{llcr}
\hline \hline $\begin{array}{l}\text { Experiment } \\
\text { (vear) }\end{array}$ & $\begin{array}{c}\text { Treatment } \\
\text { (cultivar/line) }\end{array}$ & $\begin{array}{c}\text { Chilling } \\
\text { tolerance }\end{array}$ & $\mathrm{n}^{{ }^{*}}$ \\
\hline 1A $^{\mathrm{w}}(1988)$ & Early Cherry & + & 73 \\
& New Yorker & + & 80 \\
& Redpik & + & 31 \\
& Vendor & + & 88 \\
& Rutgers alc/alc & +++ & 29 \\
& Rutgers Alc/alc & +++ & 34 \\
& Rutgers Alc/Alc & +++ & 72 \\
& 281 & +++++ & 80 \\
& $79-546$ & +++++ & 80 \\
$1 B^{\mathrm{u}}(1989)$ & New Yorker & + & 56 \\
& Vendor & + & 56 \\
& NY 246 & +++++ & 56 \\
& $79-546$ & +++++ & 56 \\
\hline
\end{tabular}

${ }^{2}$ Experiment number corresponds to figure number.

yVisually assessed chilling tolerance ( $t$ for very sensitive, +++++ for very tolerant).

$\mathrm{x}_{\mathrm{n}}=$ number of fruit sampled.

"Wilks' Criterion $\Lambda=0.382, P \leq 0.0001$; dimensionality $=1$.

"Cherry fruit, all others are standard fruit.

'Wilks' Criterion $\Lambda=0.693, P \leq 0.0001$; dimensionality $=1$.

the dark at 5C. Fruit were removed after 4 to 28 days and ripened to red-ripe (RP) in the dark at 20C. Very small fruit [L. peruvianum (L.) Mill., S. carolinense, S. pennellii Corr., S. pimpinellifolium (Juslen.) Mill.] were supported on galvanized steel mesh (1- $\mathrm{cm}^{2}$ openings) astraddle the trays to prevent rolling. Ambient (low) relative humidity $(\mathrm{RH})$ during chilling was $82 \%$ to $90 \%$, measured using a battery-powered, hand-held $\mathrm{RH}$ and temperature meter (Jenway Model 5500; Dunmow, Essex, England). High RH (93\% to 95\%) (Hardenburg et al., 1986) was maintained for fruit in sealed buckets with a flow-through air system bubbling air through a $25 \%(\mathrm{v} / \mathrm{v})$ glycerol-water solution (Johnson, 1940). Carbon dioxide in the air flow was maintained between $0.1 \%$ and $0.25 \%(\mathrm{v} / \mathrm{v})$ by adjusting the flow rate and was monitored with a Fisher gas partitioned (Model 1200; Fisher, Rochester, N. Y.) equipped with a thermal conductivity detector.

Some cultivars/lines used in 1988 and 1989 were given a subjective chilling tolerance rating from + for least tolerant to +++++ for most tolerant, derived visually from their relative tendencies to show rot, pitting, and uneven ripening. A further chilling tolerance index (TI), measuring the sensitivity to injury, was devised for other cultivars/lines tested in 1989. Twenty fruit of each cultivar/line were scored for liquefying bacterial rot $(-2)$, fungal rot $(-2)$, lack of ripening $(-2)$, and presence $(-2)$ or absence $(+2)$ of other CI symptoms, such as pitting, and values were summed to yield a TI that theoretically ranged from very tolerant $(+40)$ to highly sensitive $(-160)$. These cultivars/lines were arbitrarily categorized on the basis of their TI into four categories: 1 , very tolerant $(+38$ to +10$)$; 2 , tolerant $(+8$ to -10$) ; 3$, sensitive $(-12$ to -50$)$; 4 , very sensitive $(-52$ to -102$)$.

These cultivars/lines were also separated on the basis of fruit type (standard or plum), the color of the fruit when ripe (red or yellow), the genetic derivation of the cultivar/line, the presence of bacterial rot and lack of ripening at 20C, and on the basis of their resistance to pathogens: Verticillium albo-strum, Fusarium oxysporum f. sp. lycopersici, altenaria stem canker, anthracnose, Phytophthora infestans, Stemphylium botryosum f. sp. lycopersici, root knot nematode, and tobacco mosaic virus (IXIV).
Lines bred for resistance to the latter were exposed to TMV during selection, all others were commercial cultivars so labelled.

Color measurements were made with a Minolta Chroma Meter (CR 100 with 8-mm aperture) equipped with a data processor (DP-1OO) (Minolta, Ramsey, N. J.) and using the settings for L (lightness), a (green to red), and b (blue to yellow) (Hunter, 1948), which were standardized with a Minolta standard white reflector plate. Three readings of the $L$, $a$, and $b$ values were averaged for each tomato at each sampling. Measurements for individual fruit were made $\approx 1 \mathrm{~cm}$ from the blossom scar, which permits the greatest distinction between different stages of ripening (Garrett et al., 1960), except when comparing shoulder and blossom ends. Values of $\mathrm{L}, \mathrm{a}$, and $\mathrm{b}$ were converted to a tomato color index (coI):

$$
\mathrm{Col}=\frac{2000 \times \mathrm{a}}{\mathrm{L} \times\left(\mathrm{a}^{2}+\mathrm{b}^{2}\right) 1^{1 / 2}}
$$

The index was first used for raw tomato juice (Yeatman et al., 1960) and later found to be applicable to whole tomato fruit (Hobson, 1987; Hobson et al., 1983). The color change during chilling was quantified for each replicate fruit using the percent change in col from initial value ( $\% \Delta \mathrm{col})$, calculated for different durations $(\mathbf{x})$ of chilling:

$$
\% \Delta \operatorname{col}_{\text {Day } x}=\frac{100 \times\left(\operatorname{col}_{\text {Day } x}-\operatorname{col}_{\text {Day } 0}\right)}{\operatorname{col}_{\text {Day } 0}}
$$

Such repeated measurements of each replicate over time for different treatments can be analyzed as a split plot in time, but heterogeneity of variance over time, the inability to randomize the time variable, and the correlation between multiple measurements of the same replicate over time can limit interpretations (Eskridge and Stevens, 1987). Multiple analysis of variance (MANOVA) was proposed as an alternative to split-plot analysis (Cole and Grizzle, 1966) but requires that levels of time exceed degrees of freedom for the whole plot error and that replicates with missing values be discarded. In addition, distinct groupings of the time subplots do not exist because, for some experiments, not all treatments could be measured on the same day. To circumvent these limitations, curvilinear regressions can be fitted to the original data $(\% \Delta \mathrm{col})$ for each replicate of each treatment, followed by MANOVA of the regression coefficients (Eskridge and Stevens, 1987; Yourstone and Wallace, 1990). Treatments included various cultivars/lines, varietal characteristics, or different physical manipulations (temperature, $\mathrm{RH}$ ).

A polynomial regression of $\% \Delta \mathrm{col}$ with days of chilling was fitted for each replicate fruit:

$$
\% \Delta \mathrm{col}=b_{1} \times(\mathrm{DOC})+b_{2} \times\left|\mathrm{DOC}-\mathrm{DOC}_{\text {average }}\right|^{1 / 2}
$$

where: $\mathrm{DOC}=$ days of chilling, $\mathrm{DOC}_{\text {average }}=$ average days of chilling at which measurements were made, and $b_{1}, b_{2}=$ linear and quadratic regression coefficients.

D O C $\mathrm{C}_{\text {average }}$ was subtracted from the DOC term to reduce multicolinearity between the linear and square-root terms from $r \approx$ 0.98 to $r<0.14$. Examination of linear residual plots indicated that a polynomial model was appropriate. The regression coefficients $b_{1}$ and $b_{2}$ were analyzed as dependent variables in 22 independent MANOVA using SAS (version 5.18).

The model partitioned the total model sums of squares and cross products (SSCP) into SSCP for treatments or varietal characteristics and/or cultivars/lines, and these were designated as the $H$ matrix for significance testing. The SSCP for residuals 
Table 2. Characteristics of cultivars/lines used in 1989.

\begin{tabular}{|c|c|c|c|c|c|c|c|c|c|c|c|c|c|}
\hline \multirow{2}{*}{$\begin{array}{l}\text { Cultivars/ } \\
\text { lines }^{2}\end{array}$} & \multirow[b]{2}{*}{$\mathrm{TI}^{\mathrm{y}}$} & \multirow[b]{2}{*}{$\mathrm{TC}^{\mathrm{x}}$} & \multirow[b]{2}{*}{ Typew } & \multirow[b]{2}{*}{ Color ${ }^{v}$} & \multirow[b]{2}{*}{ Der $^{u}$} & \multicolumn{8}{|c|}{ Resistance to } \\
\hline & & & & & & Ver & Fus & TMV & Phy & Alt & Anth & Stem & $\mathrm{Nem}$ \\
\hline San Marzano & 38 & 1 & $\mathrm{P}$ & $\mathrm{R}$ & 1 & - & - & - & $?$ & - & $?$ & - & - \\
\hline Dheart & 32 & 1 & $\mathrm{P}$ & $\mathrm{R}$ & 1 & - & - & - & $?$ & - & $?$ & - & - \\
\hline Napoli & 32 & 1 & $\mathrm{P}$ & $\mathrm{R}$ & 1 & + & + & - & $?$ & - & $?$ & - & - \\
\hline $115^{\frac{1}{2}}$ & 24 & 1 & $\mathrm{P}$ & $\mathrm{R}$ & 4 & - & + & - & - & $?$ & - & $?$ & $?$ \\
\hline Better Boy & 22 & 1 & $S$ & $\mathrm{R}$ & 1 & + & + & - & $?$ & - & $?$ & - & + \\
\hline Nema 1200 & 20 & 1 & $\mathrm{P}$ & $\mathrm{R}$ & 1 & + & + & - & $?$ & - & $?$ & + & + \\
\hline Roma VFN & 18 & 1 & $\mathbf{P}$ & $\mathrm{R}$ & 1 & + & + & - & $?$ & - & $?$ & - & + \\
\hline Ieinz 1439 & 14 & 1 & $S$ & $\mathrm{R}$ & 1 & + & + & - & $?$ & - & $?$ & - & - \\
\hline USDA 68 & 12 & 1 & $S$ & $\mathrm{R}$ & 1 & + & + & - & $?$ & + & $?$ & + & - \\
\hline VF & 10 & 1 & $S$ & $\mathrm{R}$ & 1 & + & + & - & $?$ & + & $?$ & - & - \\
\hline Imp. & 10 & 1 & $S$ & $\mathrm{R}$ & 1 & + & + & - & $?$ & - & $?$ & - & - \\
\hline 97 Nor & 8 & 2 & $S$ & $\mathrm{R}$ & 3 & + & - & - & - & $?$ & - & $?$ & $?$ \\
\hline Nor & 6 & 2 & $\mathrm{P}$ & $\mathrm{R}$ & 1 & + & - & - & $?$ & - & $?$ & - & - \\
\hline 123 & 4 & 2 & $P$ & $\mathrm{R}$ & 6 & + & + & + & - & $?$ & - & $?$ & $?$ \\
\hline Celebrity & 4 & 2 & S & $\mathrm{R}$ & 1 & + & + & + & $?$ & + & $?$ & + & + \\
\hline 96 & 2 & 2 & $\mathrm{~S}$ & $\mathrm{R}$ & 3 & + & - & - & - & $?$ & - & $?$ & $?$ \\
\hline 124 & 0 & 2 & $\mathrm{P}$ & $\mathrm{R}$ & 6 & + & + & + & - & $?$ & - & $?$ & $?$ \\
\hline Bonn & 0 & 2 & $S$ & $\mathrm{R}$ & 1 & - & - & - & $?$ & + & $?$ & - & - \\
\hline VF 6 & -2 & 2 & S & $\mathrm{R}$ & 1 & + & + & - & $?$ & + & $?$ & - & - \\
\hline 132 & -4 & 2 & $S$ & $\mathrm{R}$ & 5 & + & + & - & - & $?$ & + & $?$ & $?$ \\
\hline Golden Boy & -8 & 2 & $S$ & $Y$ & 1 & - & - & - & $?$ & - & $?$ & - & - \\
\hline Flash & -10 & 2 & $S$ & $\mathrm{R}$ & 1 & + & - & - & $?$ & - & $?$ & - & - \\
\hline 98 & -16 & 3 & S & $\mathrm{R}$ & 3 & - & - & - & - & $?$ & - & $?$ & $?$ \\
\hline 13 & -26 & 3 & $S$ & $\mathrm{R}$ & 5 & + & + & - & - & $?$ & - & $?$ & $?$ \\
\hline Lemo & -28 & 3 & $S$ & $\mathrm{Y}$ & 1 & + & + & - & $?$ & + & $?$ & + & + \\
\hline Sunr & -28 & 3 & $S$ & $\mathrm{R}$ & 1 & + & - & - & $?$ & - & $?$ & - & - \\
\hline Redpik & -32 & 3 & $S$ & $\mathrm{R}$ & 1 & + & + & - & $?$ & - & $?$ & - & + \\
\hline $107 \mathrm{~V}$ & -32 & 3 & $S$ & $\mathrm{R}$ & 4 & + & - & - & - & $?$ & - & $?$ & $?$ \\
\hline Hayslip & -40 & 3 & S & $\mathrm{R}$ & 1 & + & + & - & $?$ & + & $?$ & + & - \\
\hline $77 \mathrm{~F} 2$ & -40 & 3 & $S$ & $\mathrm{R}$ & 2 & + & + & - & - & $?$ & - & $?$ & $?$ \\
\hline $106 \mathrm{~V}$ & -46 & 3 & $S$ & $\mathrm{R}$ & 4 & + & - & - & - & $?$ & - & $?$ & $?$ \\
\hline 134 & -48 & 3 & $S$ & $\mathrm{R}$ & 5 & + & + & - & - & $?$ & - & $?$ & $?$ \\
\hline 99 & -50 & 3 & S & $\mathrm{R}$ & 3 & + & - & - & - & $?$ & + & $?$ & $?$ \\
\hline $75 \mathrm{~F}_{2}$ & -52 & 4 & $S$ & $\mathrm{R}$ & 2 & + & + & - & - & $?$ & + & $?$ & $?$ \\
\hline 121 & -54 & 4 & $S$ & $\mathrm{R}$ & 4 & + & - & - & - & $?$ & - & $?$ & $?$ \\
\hline Marglobe Select & -60 & 4 & S & $\mathrm{R}$ & 1 & - & + & - & $?$ & - & $?$ & - & - \\
\hline $74 \mathrm{~F}_{1}$ & -64 & 4 & $S$ & $\mathrm{R}$ & 2 & + & + & - & - & $?$ & + & $?$ & $?$ \\
\hline 91 & -64 & 4 & $\mathrm{~S}$ & $\mathrm{R}$ & 3 & + & - & - & - & $?$ & - & $?$ & $?$ \\
\hline 97 catfaced & -64 & 4 & $S$ & $\mathrm{R}$ & 3 & + & - & - & - & $?$ & - & $?$ & $?$ \\
\hline $108 \mathrm{~V}$ & -78 & 4 & $S$ & $\mathrm{R}$ & 4 & + & - & - & - & $?$ & - & $?$ & $?$ \\
\hline Glamour & -82 & 4 & $S$ & $\mathrm{R}$ & 1 & + & - & - & $?$ & - & $?$ & - & - \\
\hline $79-546$ & -94 & 4 & $S$ & $\mathrm{R}$ & 1 & + & + & - & + & $?$ & - & $?$ & $?$ \\
\hline NY 246 & -94 & 4 & $S$ & $\mathrm{R}$ & 5 & + & + & - & + & - & $?$ & - & - \\
\hline $69 \mathrm{~F}_{3}$ & -102 & 4 & $\mathrm{~S}$ & $\mathrm{R}$ & 2 & + & + & - & - & $?$ & + & $?$ & $?$ \\
\hline
\end{tabular}

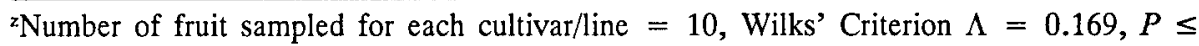
0.0001 ; dimensionality $=2$.

${ }^{\mathrm{y}} \mathrm{TI}=+38$ to -102 .

×TC $=$ chilling tolerance category; $1=$ most tolerant, $4=$ least tolerant.

"Fruit type; $\mathrm{S}=$ standard, $\mathrm{P}=$ plum.

'Color when fully ripened; $\mathrm{R}=$ red, $\mathrm{Y}=$ yellow.

${ }^{u}$ Der $=$ derivation of lines/cultivars: $1=$ cultivars, $2=$ New Yorker $\times[($ VF6 $\times$ VFN8 $) \times$ Lycopersicon peruvianum accession LA1708], $3=$ New Yorker $\times$ Solanum lycopersicoides accession LA 1964, $4=$ New Yorker $\times$ Solanum pennellii accession 87-246502, $5=$ Florida 407 (Augustine et al., 1981) $\times$ New Yorker, $6=$ TMV resistance derived from $L$. peruvianum accession 87-126915.

'Resistant (+, resistant; - , susceptible; ?, unknown) to: Ver = verticillium wilt, Fus = fusarium wilt (any race), TMV = tobacco mosaic virus, Phy $=$ Phytophthora, Alt $=$ alter naria stem canker, Anth $=$ anthracnose, Stem $=$ Stemphylium, Nem $=$ nematodes (root knot).

were designated the $E$ matrix, and the Wilks' Criterion (A) was derived as $E^{-1} \times H$ (Chatfield and Collins, 1980). When treatments showed overall significant differences based on A (Tables 1 and 3), specific significant differences between treatments were evaluated using canonical variates (CV) analysis, which provides better protection against Type I errors than confidence intervals based on A (Chatfield and Collins, 1980). Furthermore, $\mathrm{CV}$ analysis gives a graphic representation of the signif- 
Table 3. Analysis of chilling treatments.

\begin{tabular}{|c|c|c|c|c|}
\hline Experiment $^{z}$ & Treatment & $n^{y}$ & $\Lambda$ & Dimensionality \\
\hline \multirow[t]{4}{*}{$1 \mathrm{C}$} & High $T^{x}$ & 110 & $0.951^{* *}$ & 1 \\
\hline & Medium-high TI & 110 & & \\
\hline & Low-medium TI & 110 & & \\
\hline & Low TI & 110 & & \\
\hline \multirow[t]{2}{*}{$1 \mathrm{D}$} & Standard fruit & 350 & $0.895^{* * * *}$ & 1 \\
\hline & Plum fruit & 90 & & \\
\hline \multirow[t]{2}{*}{$1 \mathrm{E}$} & Rotting fruit & 44 & $0.992^{\mathrm{NS}}$ & 0 \\
\hline & Unaffected fruit & 54 & & \\
\hline \multirow[t]{2}{*}{2} & 1988 , first harvest & 80 & $0.382^{* * * *}$ & 1 \\
\hline & 1988 , second harvest & 160 & & \\
\hline \multirow[t]{2}{*}{$:$} & 1989, first harvest & 56 & & \\
\hline & 1989, second harvest & 10 & & \\
\hline \multirow[t]{4}{*}{$3 \mathrm{~A}$} & 'Rutgers' blossom end & 72 & $0.615^{* * * *}$ & 1 \\
\hline & 'Rutgers' stem end & 72 & & \\
\hline & 'Vendor' blossom end & 88 & & \\
\hline & 'Vendor' stem end & 88 & & \\
\hline \multirow[t]{2}{*}{$3 \mathrm{~B}$} & Chilled at $2 \mathrm{C}$ & 80 & $0.722 * * * *$ & 1 \\
\hline & Chilled at 5C & 80 & & \\
\hline \multirow[t]{2}{*}{$3 \mathrm{C}$} & Ambient ( $82 \%$ to $90 \%) \mathrm{RH}$ & 60 & $0.972^{\mathrm{NS}}$ & 0 \\
\hline & High $(93 \%$ to $95 \%) \mathrm{RH}$ & 59 & & \\
\hline \multirow[t]{6}{*}{$3 \mathrm{D}$} & Cultivars & 230 & $0.861 * * * *$ & 1 \\
\hline & $\times L$. peruvianum & 40 & & \\
\hline & x S. lycoperisicoides & 60 & & \\
\hline & $\times S$. pennellii & 50 & & \\
\hline & $x$ 'Florida 407' & 40 & & \\
\hline & TMV-resistant & 20 & & \\
\hline \multirow[t]{4}{*}{4} & S. carolinense & 20 & $0.497^{* * * *}$ & 2 \\
\hline & S. pennellii & 10 & & \\
\hline & L. peruvianum & 10 & & \\
\hline & L. pimpinellifolium & 10 & & \\
\hline \multirow[t]{2}{*}{5} & TMV-susceptible & 410 & $0.960^{* * * *}$ & 1 \\
\hline & TMV-resistant & 30 & & \\
\hline \multirow[t]{2}{*}{5} & Verticillium-susceptible & 60 & $0.988^{\mathrm{NSw}}$ & 1 \\
\hline & Verticillium-resistant & 380 & & \\
\hline \multirow[t]{3}{*}{5} & Alternaria-susceptible & 160 & $0.956 * * *$ & 2 \\
\hline & Alternaria-resistant & 70 & & \\
\hline & Unknown & 210 & & \\
\hline \multirow[t]{2}{*}{5} & Anthracnose-susceptible & 160 & $0.960^{* *}$ & 2 \\
\hline & Anthracnose-resistant & 50 & & \\
\hline · & Unknown & 230 & & \\
\hline 5 & Fusarium-susceptible & 180 & $0.995^{\mathrm{NS}}$ & 0 \\
\hline & Fusarium-resistant & 260 & & \\
\hline 5 & Nematode-susceptible & 170 & $0.920^{* * * *}$ & 2 \\
\hline & Nematode-resistant & 60 & & \\
\hline & Unknown & 210 & & \\
\hline 5 & Phytophthora-susceptible & 200 & $0.958 * * *$ & 1 \\
\hline & Phytophthora-resistant & 20 & & \\
\hline & Unknown & 220 & & \\
\hline 5 & Stemphylium-susceptible & 180 & $0.972^{*}$ & 1 \\
\hline & Stemphylium-resistant & 50 & & \\
\hline & Unknown & 210 & & \\
\hline $6 \mathrm{~A}$ & Red when ripe & 420 & $0.976^{* *}$ & 1 \\
\hline & Yellow when ripe & 20 & & \\
\hline $6 \mathrm{~B}$ & $79-546$ & 84 & $0.880^{* * * *}$ & 2 \\
\hline & NY 246 & 84 & & \\
\hline & New Yorker & 84 & & \\
\hline & Vendor & 82 & & \\
\hline $6 \mathrm{C}$ & Nonchilled & 112 & $0.971^{*}$ & 1 \\
\hline & Chilled 5 days, $5 \mathrm{C}$ & 110 & & \\
\hline & Chilled 15 days, $5 \mathrm{C}$ & 112 & & \\
\hline $6 C^{2}$ & $79-546$, nonchilled & 28 & $0.718^{* * * *}$ & 2 \\
\hline & $79-546$, chilled 5 days & 28 & & \\
\hline & $79-546$, chilled 15 days & 28 & & \\
\hline & NY 246, nonchilled & 28 & & \\
\hline & NY 246, chilled 5 days & 28 & & \\
\hline
\end{tabular}


Table 3. Continued.

\begin{tabular}{cllll}
\hline \hline Experiment $^{z}$ & \multicolumn{1}{c}{ Treatment } & $\mathrm{n}^{\mathrm{y}}$ & $\Lambda$ & Dimensionality \\
\hline & NY 246, chilled 15 days & 28 & & \\
& New Yorker, nonchilled & 28 & & \\
& New Yorker, chilled 5 days & 28 & & \\
& New Yorker, chilled 15 days & 28 & & \\
& Vendor, nonchilled & 28 & & \\
& Vendor, chilled 5 days & 26 & & \\
& Vendor, chilled 15 days & 28 & & \\
& Nonchilled & 20 & $0.645^{* * * *}$ & \\
& Chilled 4 days & 20 & & \\
& Chilled 8 days & 20 & & \\
& Chilled 12 days & 20 & & \\
& Chilled 16 days & 20 & & \\
\hline
\end{tabular}

${ }^{2}$ Experiment number corresponds to figure number where canonical variates are plotted.

${ }^{\mathrm{y}} \mathrm{n}=$ number of fruit sampled.

${ }^{x}$ See Materials and Methods for TI.

${ }^{\text {"}} P=0.0701$.

Not plotted in any figure

significant at $P \leq 0.05,0.01,0.001$, or 0.0001 , or nonsignificant at

$P>0.05$, respectively, by Wilks' Criterion.

icant differences between specific treatment means by a plot of the first and sometimes second CV. Data were tested for dimensionality (Tables 1 and 3) (Chatfield and Collins, 1980; Yourstone and Wallace, 1990), and honestly significant intervals (HSI) (Andrews et al., 1980) were calculated for each CV, whose experimental error standard deviation was normalized to 1.

$$
\mathrm{HSI}=\mathrm{CV} \pm \frac{q \times 1}{2 \times(\mathrm{n})^{1 / 2}}
$$

where: $q=$ studentized range statistic (Duncan, 1955) based on the degrees of freedom of the data, selected level of significance $(\alpha=0.05)$, and number of treatments being compared and $n=$ number of replicates in the treatment for which the mean is calculated.

Within each experiment and for each treatment, circles with a diameter equal to the HSI were centered on the first CV (and second $\mathrm{CV}$, where applicable) and were significantly different at the $\alpha=0.05$ level if nonoverlapping. Within an experiment, the more negative $\mathrm{CV}$ reflects the treatment with the more negative $\% \Delta$ col over time, since these two quantities are then directly proportional.

The Student $t$ test and Spearman rank correlation test were calculated using StatWorks 1.2 (Cricket Software, Malvern, Pa.).

\section{Results and Discussion}

Chilling-tolerant and chilling-sensitive standard and cherry fruit $(1988,1989)$. Tolerant lines assessed subjectively, via chilling tolerance rating, showed a more negative $\% \Delta$ col within each fruit type during chilling than did their sensitive counterparts: standard fruit, 79-546 (79) < 'New Yorker' (NY), 'Rutgers' (RG), 'Redpik' (RP), 'Vendor' (VD); cherry fruit, 281< 'Early Cherry' (EC) (Table 1, Fig. 1A). In 1989 two standard tolerant lines (79, NY 246) and two standard sensitive cultivars (NY, VD) were compared (Table 1, Fig. 1B). As in 1988 (Fig. 1A), tolerant line 79 showed a more negative $\% \Delta$ col than either of the sensitive cultivars, and NY showed a more negative $\% \Delta$ col than VD (Fig. 1B). The tolerant line 246 responded similarly to line 79. The blockage of red pigment development by $\mathrm{CI}$ is

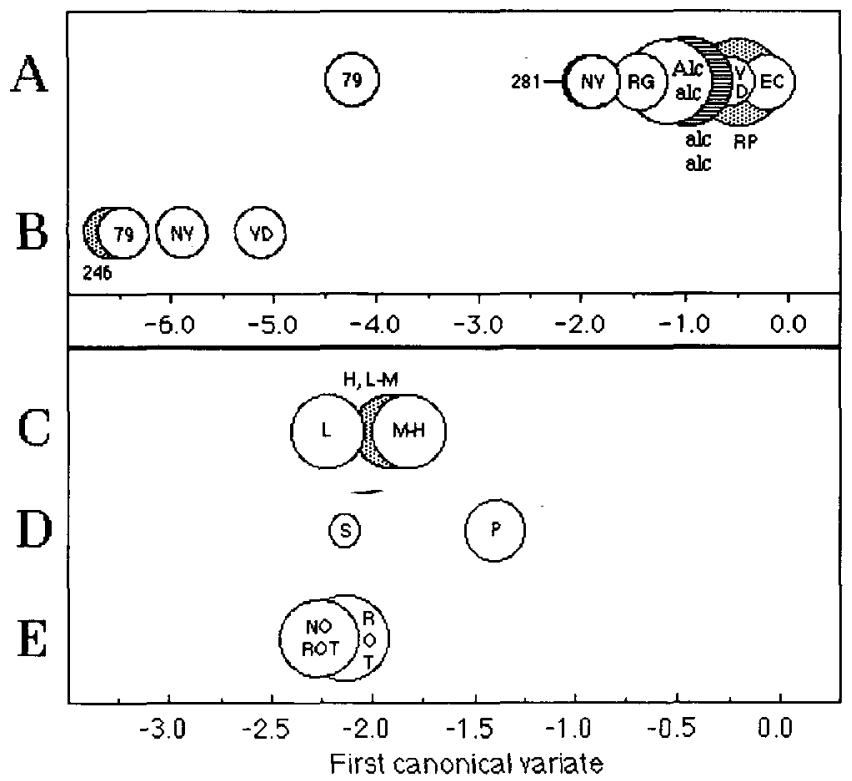

Fig. 1. Effect of treatments on color changes of MG tomato fruit during chilling: plot of first canonical variate and associated honestly significant interval. (For each experiment, the first canonical variate is directly proportional to percent change in color index, and nonoverlapping circles are significantly different at $\alpha=0.05$.) A: several cultivars/lines (1988); B: several cultivars/lines (1989); C: tolerance to chilling based on tolerance index $(\mathrm{L}=$ low, $\mathrm{L}-\mathrm{M}=$ low-medium, $\mathrm{M}-\mathrm{H}=$ medium-high, $\mathrm{H}=$ high), $\mathrm{H}$ and $\mathrm{L}-\mathrm{M}$ are superimposed; $\mathrm{D}$ : fruit type $(\mathrm{S}=$ standard, $\mathrm{P}=$ plum $)$; E: presence of bacterial rot and lack of ripening (NO ROT = no chilling symptoms of any kind, ROT = both bacterial rot and lack of ripening). Cultivars/lines: $79=$ '79-546'; $281=$ '281'; Ale/ale $=$ 'Rutgers' heterozygous for alcobaca (ale) trait; alc/ala = 'Rutgers' homozygous for alc trait; $\mathrm{EC}=$ 'Early Cherry'; $\mathrm{NY}=$ 'New Yorker'; RP $=$ 'Redpik'; RG = 'Rutgers'; VD = 'Vendor'.

likely linked to the adverse effects of chilling temperatures on . chloroplasts, which are one of the first organelles to be affected (Marangoni et al., 1989; Moline, 1976) and where pigments are synthesized and accumulated during their conversion to 
chromoplasts. The greater color change of the tolerant lines in the present study is consistent with their plastids being less damaged by chilling than those of sensitive cultivars, although this was not specifically examined.

We further observed that the more tolerant cultivars/lines compared in 1988 and 1989 developed a yellow blush more quickly than susceptible cultivars/lines when chilled for more than 20 days at 5C. The yellow blush may result from the unmasking of $\beta$ - carotene by decreasing chlorophyll levels and/ or the accumulation of chalco-naringenin, a yellow compound found in the skin of tomato fruit (Baker et al., 1982).

However, color changes during chilling, particularly the yellowing, did not appear to be related to ripening per se. Although line $79 \mathrm{MG}$ fruit appeared to be at the breaker stage after 16 days chilling at $5 \mathrm{C}$, they only began to ripen after a lag period of 4 to 5 days when placed at 20C. In contrast, Rosa (1926) found that turning' fruit stored continuously at $8 \mathrm{C}$ became red in $\approx 18$ days.

Tolerance index and color change. We investigated whether the phenomenon of greater color change for tolerant fruit (79, 246, 281) extended to other cultivars/lines assessed using TI. In contrast to our work in 1988 and the first harvest of 1989, 44 noncherry cultivars/lines (Table 2) from the later 1989 harvest showed little obvious difference in $\% \Delta$ col. For example, the usually tolerant lines 79 and 246 showed a great deal of CI and were among the most sensitive according to their TI. There was no correlation between the TI and either regression coefficient $\left(b_{2}\right.$ or $\left.b_{3}\right)$ or the CV (first or second). This held true for all fruit combined and for both plum and standard fruit $(P>$ 0.05 , Spearman rank. correlation test). Further, no differences were apparent between four tolerance categories for cultivars/ lines (Table 3, Fig. 1C). Plum fruit had significantly higher TI than standard fruit $(P \leq 0.001$, Student $t$ test $)$, yet showed a less negative $\% \Delta$ col (Table 3 , Fig. ID).

Chilled fruit that did not ripen and showed liquefying (bacterial) rot under ripening conditions were compared to chilled fruit that showed no injury. Only those cultivars/lines that had at least one fruit of each category were used. No difference in $\% \Delta$ col during chilling was found between the rotting and undamaged fruit (Table 3, Fig. 1E).

These results suggest that chilling tolerance is not related to $\% \Delta$ coL However, the 44 cultivars/lines studied in 1989 were harvested relatively late in the season (8 Sept.), and fall harvests have been shown to be more sensitive to CI than summer harvests (Kidd and West, 1933; Morris, 1953), and hours below 15.6C in..the week before harvest were found to be correlated with decay during ripening (Morris, 1953). In our work, second harvests of line 79 tended to show less negative $\% \Delta$ col than first harvests (Fig. 2). For all harvests (1988 and 1989), the greater the number of hours below $15.6 \mathrm{C}$ in the $200 \mathrm{~h}\left(8^{1 / 3}\right.$ days) before harvest, the smaller the color change during subsequent chilling (Table 3, Fig. 2). This trend was also shown in 1988 for hours below 10C (Fig. 2). Thus the 44 late-harvested cultivars/lines were more sensitive to chilling and, consequently, showed a smaller $\% \Delta$ col during postharvest chilling as compared to fruit harvested earlier. Decreased color change should reduce the ability to discriminate between levels of chilling sensitivity, leading to the nonsignificant results obtained with the 44 cultivars/lines. This conclusion is further supported by yearly differences in $\% \Delta$ col. Line 79 fruit grown in 1989 showed a less negative $\% \Delta$ col than those grown in 1988 (Fig. 2 ). This would again suggest that line 79 fruit were more sensitive in 1989 than in 1988, possibly because the 1988 growing

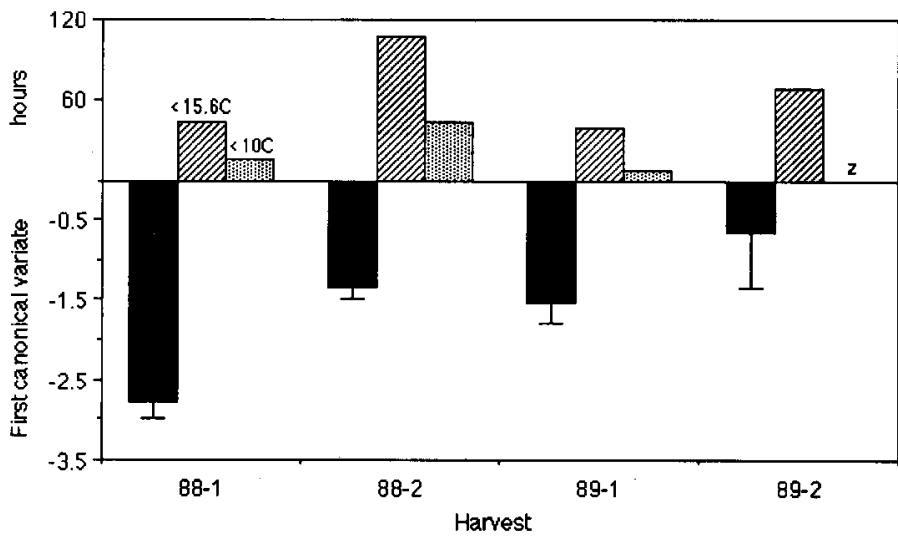

Fig. 2. Effect of hours of preharvest chilling in the field on color change of MG tomato fruit during postharvest chilling. 88-1 = 19 Aug. $1988 ; 88-2=16$ Sept. $1988 ; 89-1=21$. Aug. $1989 ; 89-2=$ 8 Sept. 1989.

'No hours below 10C were recorded for 89-2.

season generally was hot and dry, while the 1989 season was very wet (Morris, 1953). In addition, Gonzalez-Ramirez et al. (1978) found that low temperatures in the field before harvest increased CI but did not change relative tolerance of different cultivars/lines. This finding was confirmed within our cultivars/ lines of known tolerance (Fig. 1 A and B), where the overall ordering of tolerant and sensitive cultivars/lines was the same for two harvests, but the differences between cultivars/lines tended to be smaller in 1989 than in 1988.

Effect of the alc (alcobaca) trait (1988). Although there was no apparent difference in chilling sensitivity between fruit of $\mathrm{RG}(A l c / A l c)$, alc $\mathrm{F}_{1}(A l c / a l c)$, and alc/alc fruit, there was a tendency toward a more negative $\% \Delta$ col during chilling with increased Alc dosage (Table 1, Fig. 1A). This is probably related to relative ripening rates of the three lines (ale/ale < Alc/alc < Alc/Alc) (Mutschler, 1984) rather than to any differences in chilling tolerance, as those genotypes that show the slowest color development during ripening are likely to show the least $\% \Delta$ col during chilling.

Comparison of shoulder vs. blossom end. In $1989, \% \Delta \mathrm{col}$ was measured on both the shoulder and blossom ends of RG and VD fruit. As in 1988 (Fig. 1A), the more tolerant RG fruit showed a more negative $\% \Delta$ col than VD fruit (Table 3, Fig. $3 \mathrm{~A})$. The stem end showed a more negative $\% \Delta$ col than the blossom end (Fig. 3A). The difference in $\% \Delta$ col between shoulder and blossom end was greater for RG than VD fruit at all chilling times $(P \leq 0.001$, Student $\mathrm{t}$ test $)$. This was due to a greater percent color change of the dark-green shoulder of RG when compared to the uniformly colored VD fruit.

Effect of chilling temperature, 2C vs. 5C (1988). Line 79 fruit held at $2 \mathrm{C}$ did not yellow as much as fruit held at $5 \mathrm{C}$. Color measurements verified that there was greater color change at $5 \mathrm{C}$, i.e., there was a more negative $\% \Delta \mathrm{col}$ at $5 \mathrm{C}$ than at $2 \mathrm{C}$ (Table 3, Fig. 3B). These results are similar to those of Diehl (1924), who found neither color development nor loss of chlorophyll in tomatoes held at 0C up to 30 days, while Rosa (1926) and Furlong (1946) saw some yellowing at 4C and 5C, respectively.

Effect of relative humidity (1988). The differences in RH used in the present experiments had no effect on surface color of fruit of cherry line 281 during chilling, supporting the use of the regular storage chambers at humidities of $82 \%$ to $90 \%$ for chilling experiments. However, there was a tendency for less change 


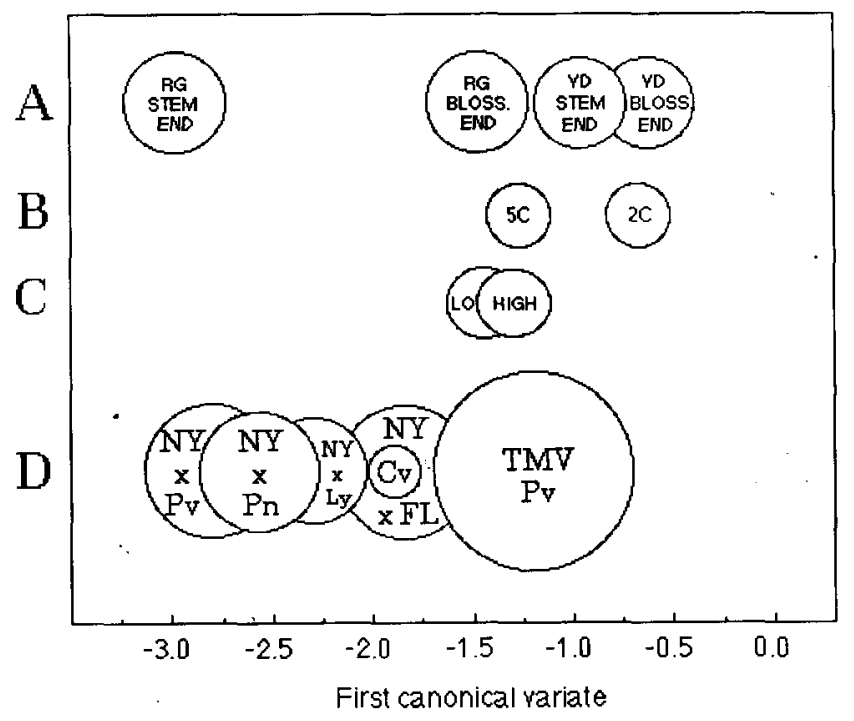

Fig. 3. Effect of region of the fruit, conditions, and genetic origin on color change of mature-green tomato fruit during chilling: plot of first canonical variate and associated honestly significant interval. A: Stem vs. blossom (BLOSS) end, 'Rutgers' (RG), and 'Vendor' (VD) fruit (1988); B: chilling at 2C vs. 5C, with line 79 (1988); C: low (LO) VS. high relative humidities, with line 281 (1988); D: breeding origin of cultivars/lines, where $\mathrm{Cv}=$ cultivars, $\mathrm{NY} \times \mathrm{Pv}$ $=$ 'New Yorker' $\times[(\mathrm{VF} 6 \times \mathrm{VFN} 8) \times$ Lycopersicon peruvianum accession LA1708], NY $\times$ Ly $=$ 'New Yorker' $\times$ Solanum lycopersicoides accession LA1964, NY $\times$ Pn $=$ 'New Yorker' $\times$ S. pennellii accession 87-246502, NY $\times$ FL $=$ 'Florida' 407' $\times$ 'New Yorker', TMV $\mathrm{PV}=\mathrm{TMV}$ resistance derived from $L$. peruvianum accession 87-126915.

in the surface color of fruit chilled at high RH, i.e., they showed the most negative $\% \Delta$ col (Table 3, Fig. 3C). High RH can reduce the development of symptoms of CI. Banana (Musa acuminata Colla) fruit chilled at 5C developed considerably more skin pitting as RH decreased from $100 \%$ to $50 \%$ (Pantastico et al., 1967). Similar results were obtained for grapefruit (Citrus $\times$ paradisi Macfady) and limes [Citrus aurantifolia (Christm.) Swingle] (Pantastico et al., 1968). An RH range lower than $82 \%$ to $90 \%$ may, therefore, have a significant effect on the development of surface color during chilling, although, unlike in pitting, the involvement of water loss is conjectural.

Effects of genetic origin, wild genera (1989). Several differences were apparent among the 44 cultivars/lines when separated based on their genetic origin (Table 3, Fig. 3D). Fruit derived from crosses with wild genera (L. peruvianum accession LA1708 and S. pennellii) showed a more negative $\% \Delta$ col during chilling than the commercial cultivars tested, while crosses with L. Iycopersicoides showed a strong and similar tendency (Fig. 3D). When four wild genera, S. carolinense, S. pennellii, L. peruvianum, and L. pimpinellifolium, were compared during chilling, L. peruvianum stood out with its positive CV (Table 3, Fig. 4), possibly due to the confounding factor of its purple surface. None of the wild genera showed any obvious symptoms of cr.

Effects of disease resistance (1989). TMV-resistant fruit from both lines and cultivars showed a less negative $\% \Delta$ col than nonresistant fruit (Table 3, Fig. 5). Lines bred for TMV resistance (lines 123, 124) showed a similar response when compared with other categories of genetic origin (Fig. 3D), except those lines derived from 'Florida 407' (Augustine et al., 1981). When stored at the nonchilling temperature of $12 \mathrm{C}$, fruit of

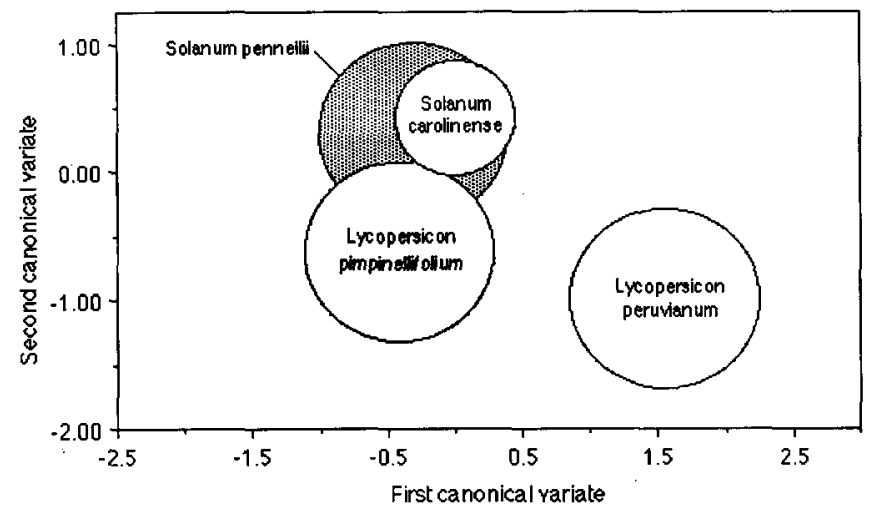

Fig. 4. Effect of chilling on color changes of some wild genera (1989): plot of first and second canonical variate and associated honestly Significant interval.

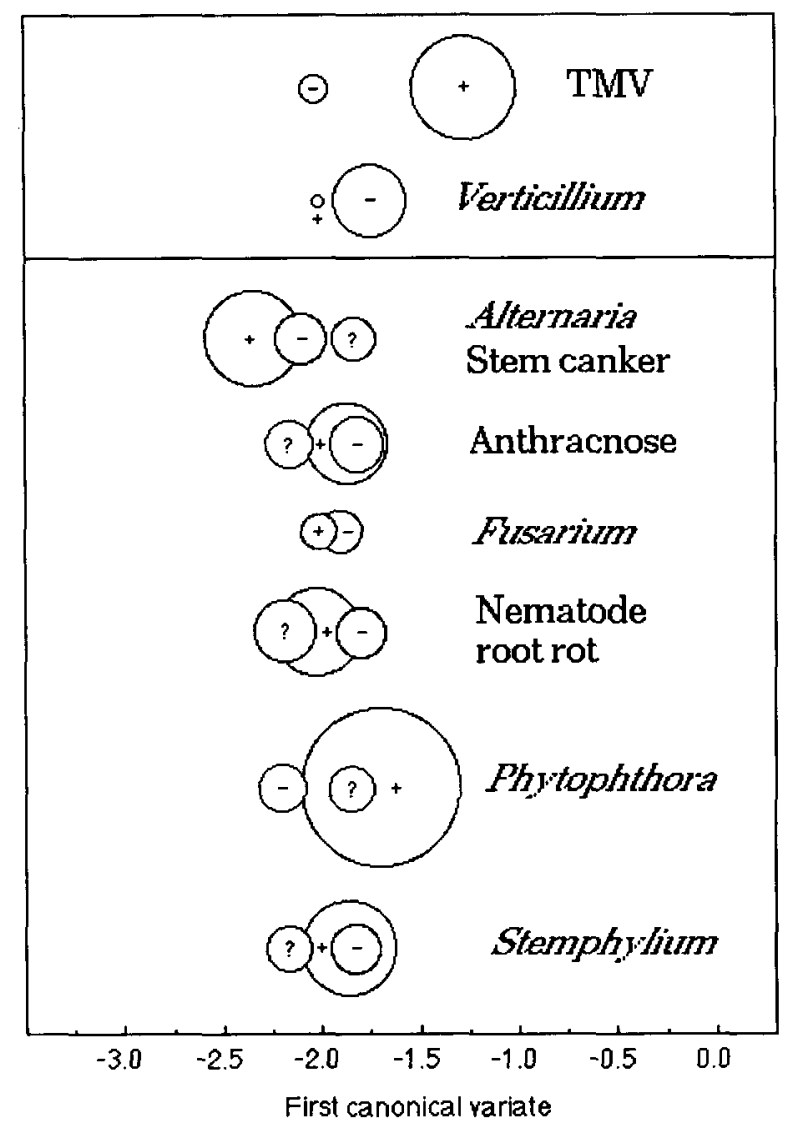

Fig. 5. Effect of resistance to pathogens on color changes of MG tomato fruit during chilling (1989): plot of first canonical variate and associated honestly significant interval. + for resistant, - for sensitive, ? for unknown.

cultivars resistant to TMV developed more color (based on CO1) than TMV-susceptible varieties (Ottosson and Wiberg, 1977), but this color change was associated with ripening.

There were distinctly different CI symptoms between TMVresistant and TMV-susceptible VD fruit. The latter showed surface pitting and discoloration mainly on their top half, similar to that of TMV-susceptible NY, RG, RP, and 79, while there was no pitting in TMV-resistant VD fruit, but large areas over locules remained yellow after the remainder of the fruit had turned red. Fruit of TMV-resistant cultivars maintained elevated sugar levels longer during ripening and had a higher acid content 
than TMV-susceptible, so it is apparent that this trait does influence tomato fruit maturation (Ottosson and Wiberg, 1977).

Verticillium resistance led to a more negative $\% \Delta$ col (Table 3, Fig. 5). Disease resistance to Fusarium, Alternaia, anthracnose, nematodes, Phytophthora, or Stemphylium had no effect (Table 3, Fig. 5), although there was a tendency for Phytophthora resistance to lead to a less negative \% $\Delta$ col (Fig. 5).

Effects of chilling duration on subsequent ripening (1989). The ultimate color of nonchilled ripe fruit affected the $\% \Delta$ col of chilled MG fruit, with fruit that are yellow when ripe showing the most negative $\% \Delta$ col (Table 3, Fig. 6A).

The $\% \Delta$ col during ripening (based on day 0 of ripening after chilling) was more negative for the chilling-tolerant line 79 than for any other cultivar/line, i.e., line 79 ripened more quickly. Chilling-sensitive VD showed a less negative $\% \Delta$ col during ripening than all other cuItivars/lines, except NY 246 (Table 3, Fig. 6B). Duration of chilling had no effect on ripening rate across all cultivars/lines, but there was a tendency toward a faster ripening rate with increased chilling (Table 3, Fig. 6C). Individually, line 79 showed an effect of chilling on ripening, with the 15-day chilled fruit ripening faster than those chilled 5 days or nonchilled (Table 3: Expt. $6 C^{v}$ ). These results were unexpected since previous work showed that an increase in chilling duration for MG fruit was reflected in a slowing of subsequent ripening (Rosa, 1926; Saltveit and Cabrera, 1987). While we measured ripening based on the degree of color change and their assessment was based on days to red-ripe, nonetheless such differences in method are unlikely to have led to such contrary results. Thus, we cannot account for this difference in outcome.

Effects of chilling duration on subsequent "ripening" in $S$. carolinense (1989). The fruit of S. carolinense normally turn a bright yellow in the wild, but neither nonchilled nor chilled fruit "ripened" at 20C even after 2 months. Chilled fruit showed no outward signs of CI, but showed a less negative $\% \Delta$ col than

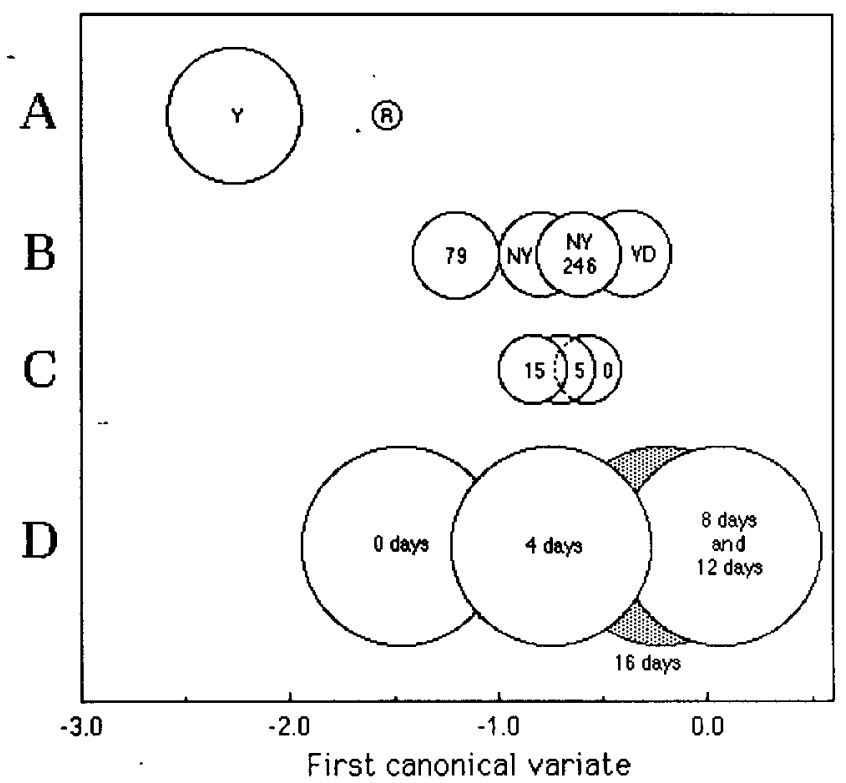

Fig. 6. Fruit color and the effect of chilling duration on ripening (1989): plot of first canonical variate and associated honestly significant interval. A: fruit color when ripe, $\mathrm{R}=$ red, $\mathrm{Y}=$ yellow; B: ripening of four cultivars/lines for all chilling times [Line 79-546 (79), line NY 246, 'New Yorker' (NY), 'Vendor' (VD)]; C: effect of 0 to 15 days of chilling on ripening across all cultivars/lines; D: effect of 0 to 16 days of chilling on "ripening" of Solarium carolinense. unchilled fruit under ripening conditions following chilling up to 8 days; thereafter, $\% \Delta$ col leveled off (Table 3, Fig. 6D). Thus, nonchilled fruit showed a small color change that was detectable only electronically, and this small change was decreased by chilling.

Changes in the surface color of MG fruit during chilling were thus not correlated overall with relative chilling sensitivity, although chilling-induced color changes sometimes differentiate between relative sensitivity of cultivars/lines within a fruit type. Preharvest field temperatures affected postharvest chilling sensitivity. The number of hours below $15.6 \mathrm{C}$ in the $200 \mathrm{~h}$ before harvest was positively correlated with postharvest chilling sensitivity. Fruit from early harvests were less chilling-sensitive than those from late harvests, emphasizing that comparative studies of chilling sensitivity must take harvest time into consideration. A high vs. ambient $\mathrm{RH}$ did not affect chilling-induced $\% \Delta$ col, suggesting that unregulated RH should not normally confound results, although $\mathrm{RH}$ less than $82 \%$ to $90 \%$ may enhance injury. TMV resistance led to less and Verticillium resistance led to more chilling-induced color change, while resistances to Fusarium, Alternaria, anthracnose, nematodes, Phytophthora, or Stemphylium had no effect. It was apparent from our results that harvest date had a definite effect on chilling-induced surface color in MG fruit, but further work is required to elucidate its effect more fully.

\section{Literature Cited}

Abdel-Maksoud, M. M., A.B. Abou-Aziz, A.S. Abdel-Kader, and K.A. Abdel-Samie. 1974. Influence of growing season and storage temperature on chilling injury of tomato fruit. Egyptian J. Hort. 1:271274.

Abou-Aziz, A. B., M.M. Abdel-Maksoud, K.A. Abdel-Samie, and A.S. Abdel-Kader. 1974a. Comparative effects of chilling injury on three cultivars of tomato harvested at mature-green stage. Gartenbauwissenschaft 39:191-198.

Abou-Aziz, A. B., M.M. Abdel-Maksoud, K.A. Abdel-Samie, and A.S. Abdel-Kader. 1974b. Effect of picking stage and temperature on quality and ripening of tomato fruits. Gartenbauwissenschaft 39:3745.

Andrews, H. P., R.D. Snee, and M.H. Sarner. 1980. Graphical display of means. Amer. Stat. 34:195-199.

Augustine, J. J., R.B. Volin, D.S. Burgis, P.H. Everett, N.C. Hayslip, H.H. Bryan, D.D. Gull, and J.P. Crill. 1981. Florida 1A, Florida 1B, Florida 1C. Three jointed fresh market tomato selections of Florida 1 resistant to race 1 and 2 of fusarium wilt and verticillium wilt. Univ. Florida (Gainesville) Agr. Expt. Sta. Circ. S-282.

Autio, W.R. and W.J. Bramlage. 1986. Chilling sensitivity of tomato fruit in relation to ripening and senescence. J. Amer. Soc. Hort. Sci. 111:201-204.

Baker, E. A., M.J. Bukovac, and G.M. Hunt. 1982. Composition of tomato fruit cuticle as related to fruit growth and development. p. 33-44. In: D.F. Cutler, K.L. Alvin, and C.E. Price (eds.). The plant cuticle. Academic, New York.

Chatfield, C. and A.J. Collins. 1980. Introduction to multivariate analysis. Chapman and Hall, New York.

Cole, J.W.L. and J.E. Grizzle. 1966. Applications of multivariate analysis of variance to repeated measurements experiments. Biometrics 22:810-828.

Diehl, H.C. 1924. The chilling of tomatoes. U.S. Dept. Agr. Dept. Circ. 315.

Duggar, B.M. 1913. Lycopersicin, the red pigment of the tomato, and the effects of conditions upon its development. Washington Univ. Studies 1:22-45.

Duncan, D.B. 1955. Multiple range and multiple $F$ tests. Biometrics “ 11:1-42.

Efiuvwevwere, B.J.O. and S.N. Thorne. 1988. Development of chill- 
ing injury symptoms in stored tomato fruit (Lycopersicon esculentum Mill). J. Sci. Food Agr. 44:215-226.

Eskridge, K.M. and E.J. Stevens. 1987. Growth curve analysis of temperature-dependent phenology models. Agron. J. 79:291-297.

Furlong, C.R. 1946. The storage and ripening of green tomatoes, with special reference to open-air fruit and end-of-season fruit from glasshouses. J. Pomol. Hort. Sci. 22:197-208.

Garrett, A.W., G.R. Ammerman, N.W. Desrosiers, and M.L. Fields. 1960. Effect of color on marketing of fresh tomatoes. Proc. Amer. Soc. Hort. Sci. 76:555-559.

Gonzalez-Ramirez, A., J.R. Hicks, and M.H. Tabacchi. 1978. Chilling sensitivity differences in tomato lines. HortScience 13:390. (Abstr.)

Hardenburg, R. E., A.E. Watada, and C.Y. Yang. 1986. The commercial storage of fruits, vegetables, and florist and nursery stocks. U.S. Dept. Agr. Hdbk. 66.

Harvey, R.B. and R.C. Wright. 1922. Frost injury to tomatoes. U.S. Dept. Agr. Bul. 1099.

Hobson, G.E. 1981., The short-term storage of tomato fruit. J. Hort. Sci. 56:363-368.

Hobson, G.E. 1987. Low-temperature injury and the storage of ripening tomatoes. J. Hort. Sci. 62:55-62.

Hobson, G. E., P. Adams, and T.J. Dixon. 1983. Assessing the color of tomato fruit during ripening. J. Sci. Food Agr. 34:286-292.

Hunter, R.S. 1948. Photoelectric color-difference meter. J. Optical Soc. Amer. 38:661. (Abstr.)

Johnson, C.G. 1940. The maintenance of high atmospheric humidities for entomological work with glycerol-water mixtures. Ann. Appl. Biol. 27:295-299.

Kader, A.A. and L.L. Morris. 1976. Correlating subjective and objective measurements of maturation and ripeness of tomatoes. Proc. 2nd Tomato Quality Workshop, July 1976, Davis, Calif. p. 57-62.

Kidd, F. and C. West. 1933. Low-temperature tolerance of summerand autumn-grown hot-house tomatoes. Rpt. Food Investigation Board 1932 (Great Britain) :82-83.

King, M.M. and P.M. Ludford. 1983. Chilling injury and electrolyte leakage in fruit of different tomato cultivars. J. Amer. Soc. Hort. Sci. 108:74-77.

Marangoni, A. G., A.K. Smith, R.Y. Yada, and D.W. Stanley. 1989. Ultrastructural changes associated with chilling injury in maturegreen tomato fruit. J. Amer, Soc. Hort. Sci. 114:958-962.

McColloch, L.P. and J.T. Worthington. 1952. Low temperature as a factor in the susceptibility of mature-green tomatoes to Alternaria rot. Phytopathology 42:425-427,
McColloch, L.P. and J.T. Worthington. 1954. Ways to prevent chilling of mature-green tomatoes. Pre-Pack Age 7(6):22-25.

Moline, H.E. 1976. Ultrastructural changes associated with chilling of tomato fruit. Phytopathology 66:617-624.

Morris, L.L. 1953. Temperature in relation to the ripening behavior of tomato. Proc. Conf. Transport of Perishables, 5-7 Feb. 1953, Davis, Calif. p. 141-146.

Morris, L.L. 1982. Chilling injury of horticultural crops: An overview. HortScience 17:161-162.

Mutschler, M.A. 1984. Ripening and storage characteristics of the 'Alcobaca' ripening mutant in tomato. J. Amer. Soc. Hort. Sci. 109:504-507.

Ogura, N., H. Nakagawa, and H. Takehana. 1975. Studies on the storage temperature of tomato fruits, Part I. Effect of high temperature-short term storage of mature green tomato fruits on changes of their chemical composition after ripening at room temperature (English summary). Nippon Nôgeikagaku Kaishi 49:189-196.

Ottosson, L. and L. Wiberg. 1977. Post-harvest changes in greenhouse tomatoes Lycopersicon esculentum L. [sic]. Acts Hort. 62:267-274.

Pantastico, E. B., W. Grierson, and J. Soule. 1967. Chilling injury in tropical fruits: I. Bananas (Musa paradisiaca var. Sapientum CV. Lacatan). Proc. Trop. Reg. Amer. Soc. Hort. Sci. 11:83-91.

Pantastico, E. B., J. Soule, and W. Grierson. 1968. Chilling injury in tropical and subtropical fruits: II. Limes and grapefruit. Proc. Trop. Reg. Amer. Soc. Hort. Sci. 12:171-183.

Rosa, J.T. 1926. Ripening and storage of tomatoes. Proc. Amer. Soc. Hort. Sci. 23:233-242.

Saltveit, M. E., Jr., and R.M. Cabrera. 1987. Tomato fruit temperature before chilling influences ripening after chilling. HortScience 22:452454.

Segall, R. H., N.C. Hayslip, and J.M. Walter. 1963. Effect of postharvest temperature on several tomato varieties harvested at the mature-green stage. Proc. Fla. State Hort. Soc. 76:172-177.

Tomkins, R.G. 1963. The effects of temperature, extent of evaporation, and restriction of ventilation on the storage life of tomatoes. J. Hort. Sci. 38:335-347.

Yeatman, J. N., A.P. Sidwell, and K.H. Norris. 1960. Derivation of a new formula for computing raw tomato juice color from objective color measurements. Food Technol. 14:16-20.

Yourstone, K.S. and D.H. Wallace. 1990. Effects of photoperiod and temperature on rate of node development in indeterminate bean. J. Amer. Soc. Hort. Sci. 115:824-828. 